\title{
Justice Douglas and Lawyers with a Cause
}

\section{Thomas I. Emerson ${ }^{\dagger}$}

Throughout his life Justice Douglas was a controversial figure. Although history will certainly place him among the greatest of our Justices, he did not, during his lifetime, appeal to everybody. Much of the legal academic elite indicted him for failing to follow "neutral principles," official bureaucracies were inclined to feel he ignored their efforts to maintain effective government, and large segments of the establishment looked upon him with disfavor if not alarm. On the other hand, Justice Douglas had a remarkably broad constituency. It extended far beyond the legal profession, to ordinary citizens, to the molders of opinion, to environmentalists, to peoples of foreign lands. My concern here, however, is with his impact upon lawyers.

Justice Douglas was a source of inspiration and hope for many members of the legal profession. But his presence on the Supreme Court was of special importance to liberal, progressive, and radical lawyers, to young idealistic law students and practitioners, to- older lawyers with old-fashioned values, to that part of the legal academic world that was attempting to push beyond legal realism, and in general to all lawyers fighting for causes and seeking to change the world. Whatever the crisis of the time-McGarthyism, civil rights, the Vietnam War, Watergate-these lawyers could find understanding and support in Justice Douglas. More than that, they often found new ideas, for Justice Douglas was usually ahead of his constituency.

Justice Douglas's influence lay not only in his extraordinary ability, though a lesser person taking his course might not have survived; nor only in his courage, though that was an integral part; nor only in his length of service on the Supreme Court, though that heightened his impact. It also lay in a series of themes that he consistently sounded throughout his life and work. Those themes, which in combination made Douglas a unique Justice, could be illustrated profusely from his legal opinions and other writings. They can only be sketched in bare outline here.

At the core of Justice Douglas's world is his view of the role of the individual in American life. From Justice Brandeis, whom Justice Douglas succeeded on the bench and who greatly influenced him, he

Lines Professor of Law Emeritus, Yale Law School. 
took the concept of the right of the individual to self-realization. $\mathrm{He}$ felt strongly not only that the Bill of Rights was intended as "a safeguard of conscience and human dignity," 1 but that it was meant to assure "the autonomous control over the development and expression of one's intellect, interests, tastes, and personality."2 For Justice Douglas this right of self-realization was not passive or self-indulgent, but active and expanding, involving a willingness to struggle. "The great values of freedom are in the opportunities afforded man to press to new horizons, to pit his strength against the forces of nature, to match skills with [not against] his fellow man." 3 Above all he rejected the notion of the individual as conformist, compliant, or submissive to authority. Rather he urged Americans to be self-reliant, innovative, dissident, to have a "real appetite for independence." $4 \mathrm{He}$ summed it up by saying, "The strength of our system is in the dignity, the resourcefulness, and the independence of our people."

The call was for persons with an active social conscience, not for those willing to rest comfortably on the status quo. The lawyers who struggled for causes, and worked with people likewise struggling, shared these feelings and found encouragement in them.

Complementary to Justice Douglas's view of the individual was a life-enhancing view of American society. $\mathrm{He}$ did not visualize America as static, hide-bound, run by "faceless, nameless bureaucrats," 6 inhabited by people whose main interest was to get along. Rather, he conceived it as being alive, vibrant, and somewhat contentious. Thus, one function of free speech was "to invite dispute. It may indeed best serve its high purpose when it induces a condition of unrest, creates dissatisfaction with conditions as they are, or even stirs people to anger." America ought to be active, innovative, and changing. Moreover, he did not look at America as consisting only of its people, living in isolation, but rather as including all of nature. Hence its trees, its mountains, its lakes, and its rivers should be entitled to representation in the decisionmaking process. ${ }^{8}$

Moreover, and perhaps most important of all, Justice Douglas thought of America as representing something special in the history

1. Ullmann v. United States, 350 U.S. 422,445 (1956). All citations to cases and books, unless otherwise noted, are to the writings of Justice Douglas.

2. Roe v. Wade, 410 U.S. 113, 211 (1973).

3. Barsky v. Board of Regents, 347 U.S. 442,472 (1954).

4. Of Men and Mountajns 329 (1950).

5. Public Utils. Comm'n v. Pollak, 343 U.S. 451,469 (1952).

6. Broadrick v. Oklahoma, 413 U.S. 601, 621 (1973).

7. Terminiello v. Chicago, 337 U.S. 1, 4 (1949).

8. Sierra Club v. Morton, 405 U.S. $727,741-43$ (1972). 
of civilization. To him, America was an ideology, an "-ism." $\mathrm{He}$ recognized that its shape and meaning were not yet finished; the job had to be completed. But he believed in progress. Despite adverse trends and specific setbacks, he was optimistic that the vision could be realized. Here again the appeal of Justice Douglas was not to those forces in society that were exploiting America. But it did summon to action those who shared his faith in progress.

A third theme in the work of Justice Douglas was his resolute grasp of social reality, despite the legal trappings in which the issues were presented. This quality he also took from Justice Brandeis and from the Brandeis Brief. Justice Douglas was skeptical of legal formulations and impatient with those who relied upon them without examining whether they were still rooted in the facts. "Formulas of respect for constitutional safeguards," he said, "cannot prevail over the facts of life which contradict them. They may not become a cloak for inquisitorial practices and make an empty form of the due process of law for which free men fought and died to obtain."'

Justice Douglas's close touch with social reality was evident in numerous opinions. In reviewing the prosecution of the Communist Party leaders for their advocating overthrow of the government by force and violence, he applied the "clear and present danger" test-a formula he later rejected-by examining in great detail the extent of any threat posed by that group to the United States government, concluding that to believe there was any danger "is to believe the incredible." 10 In considering the validity of a loyalty program for teachers, he spelled out at length the "pall ... cast over the classrooms" by such measures. ${ }^{11} \mathrm{He}$ pointed out the potential for suppression in allowing the police to stop a public meeting at the first sign of hostility to the speaker, ${ }^{12}$ the significance of being able to hold a demonstration at a symbolic site such as a prison, ${ }^{13}$ the impact of prolonged police interrogation upon a fifteen-year-old youth, ${ }^{14}$ the realities behind closing down all public swimming pools when blacks begin to seek equality in public accommodations. ${ }^{15}$ Moreover, his capacity for knowing what was going on extended beyond the area of civil liberties; it included the problems of business, labor, consumers, the environment, and many other matters.

9. Haley v. Ohio, 332 U.S. 596, 601 (1948).

10. Dennis v. United States, 341 U.S. 494,589 (1951).

11. Adler v. Board of Educ., 342 U.S. 485, 510 (1952).

12. Feiner v. New York, 340 U.S. 315, 331 (1951).

13. Adderley v. Florida, 385 U.S. 39,49 (1966).

14. Haley v. Ohio, 332 U.S. 596, 599-601 (1948).

15. Palmer v. Thompson, 403 U.S. 217, 235 (1971). 
This quality in Justice Douglas was most reassuring to lawyers on the front lines, who sometimes wondered whether their sense of reality had deserted them. Thus, when a majority of the Supreme Court upheld the suspension from medical practice of a doctor who had relied upon his First Amendment rights to refuse to answer certain questions put by the House Committee on Un-American Activities, there was a breath of fresh air in Justice Douglas's dissenting observation: "When a doctor cannot save lives in America because he is opposed to Franco in Spain, it is time to call a halt and look critically at the neurosis that has possessed us."16 Similarly, it was comforting, when the majority dismissed an effort by citizens to enjoin Army Intelligence from widespread political surveillance, saying that the petitioners had suffered only a "subjective 'chill," "17 to have Justice Douglas respond that such a claim to lack of standing "is too transparent for serious argument."18

Justice Douglas's approach to social facts, however, had a more farreaching impact. In effect, he was extending the concept of the Brandeis Brief beyond economic issues to questions of individual rights. In this respect his approach had an important liberating influence. It encouraged lawyers not only to state and apply evolving principles of law, but also to seek to alter the Supreme Court's view of reality.

In essence, Justice Douglas was interested in using the law to get the job done, a job he saw needed to be done. He was not interested in mere abstractions, no matter how high the level. This passion for reality has been the major basis for criticism that Justice Douglas was resultoriented, unprincipled, and indeed anti-intellectual. It can also be viewed as refreshing and creative jurisprudence.

A fourth characteristic of Justice Douglas, one that he shared with Justice Black, was his understanding of, and empathy with, the disadvantaged. Despite his gruffness of manner at times, Justice Douglas had remarkable rapport with common people. He could talk with them and liked to do so. "[A]Il men have a common humanity," he asserted; "there is a oneness in the world which binds all men together."10

Justice Douglas was well aware of who the disadvantaged were; he had lived among them as a youth and, when he reached the summit of government, he continued to keep in touch with them and to educate himself first-hand about their changing needs. They were the poor, the uneducated, the racial and religisus minorities, the unpopular political groups, persons in institutions, Wobblies, sharecroppers. In essence,

16. Barsky v. Board of Regents, 347 U.S. 442,474 (1954).

17. Laird v. Tatum, 408 U.S. 1, 13 (1972) (opinion of the Court).

18. Id. at 24 .

19. An almanac of Liberty 3 (1954). 
they were the dispossessed, the people who were not represented in public decisionmaking. As Justice Douglas knew, the fact that a legislature or an administrative agency had acted did not mean that the views or interests of all people had been taken into account. America was not a club.

Justice Douglas understood the plight of the dispossessed. He knew what it meant when "public opinion casts a person into the outer darkness." ${ }^{20}$ And he endeavored to bring them into the mainstream of American life, to help them share the benefits of the law, its advantages, its protections, and its remedies. "Freedom of speech, freedom of the press, freedom of religion are available to all," he contended, "not merely to those who can pay their own way."21 And when the Supreme Court held that the Fourth Amendment protection against unreasonable searches and seizures did not allow a mother on welfare to refuse to permit a caseworker to visit her home without a warrant, he insisted in dissent: "If the welfare recipient was not Barbara James but a prominent, affluent cotton or wheat farmer receiving benefit payments for not growing crops, would not the approach be different?" 22

Ultimately, Justice Douglas's sensitivity to the situation of the dispossessed grew out of his attitude toward nature. "[N]ature was a great leveler," he wrote of his experiences climbing mountains; "[m]en fighting a blizzard on the plains or an angry storm at sea at once became equal. ... The fact that a person lived on one side of the railroad tracks rather than on the other made no difference." ${ }^{23}$ Lawyers taking the problems of the dispossessed to court were sure to receive a sympathetic hearing from Justice Douglas.

A fifth theme that Justice Douglas constantly expounded was that the achievement of liberty is a never-ending struggle. "All power is a heady thing," he remarked. ${ }^{24}$ And there are always people in the society who want to diminish the liberty of others. Hence, the life of a responsible citizen can never be comfortable.

The main threat to liberty, of course, comes from governmental power. Unlike some members of the Supreme Court, Justice Douglas was not inclined to pay deference to the actions of government officials or to presume that the government's power was always exercised for the public good. On the contrary, he tended to view the government

20. Ullmann v. United States, 350 U.S. 422, 454 (1956).

21. Murdock v. Pennsylvania, 319 U.S. 105, 111 (1943).

22. Wyman v. James, 400 U.S. 309, 332 (1971).

23. OF Men And Mountains, supra note 4, at 210-11.

24. Chandler v. Judicial Council, 398 U.S. 74, 137 (1970). 
as potential malefactor, not to be trusted. Toward the end of his tenure he declared, "The intrusion of government into this domain [freedom of the press] is symptomatic of the disease of this society. As the years pass the power of government becomes more and more pervasive. It is a power to suffocate both people and causes. Those in power, whatever their politics, want only to perpetuate it." 25

Justice Douglas was likewise concerned with private power. Here, also, he followed Justice Brandeis in feeling that "size can become a menace."26 Believing that "all power tends to develop into a government in itself," he concluded that "Power that controls the economy should be in the hands of elected representatives of the people, not in the hands of an industrial oligarchy," and, hence, "Industrial power should be decentralized."2t

Under these circumstances, Justice Douglas felt, the ability of "We, the People" to maintain our sovereignty over public and private power could only be realized by a permanent militancy. It would take a lot of energy. Life, as he was fond of saying, was "getting in and out of trouble."

At the center of Justice Douglas's philosophy was a sixth theme. This was that the judiciary should take a leading part in the affirmative struggle to maintain and advance the American system. It was the business of the courts to be guardians of what was special about America, to "become the champions of the virtues that have given the West great civilizations." ${ }^{28}$ Particularly was it the duty of the courts to safeguard the Constitution, to keep it vigorous and undiluted.

In performing this function, Justice Douglas was always ready to take on the major centers of power and influence in American society. Thus, he concurred with the ruling against President Truman's seizure of the steel mills, ${ }^{20}$ wanted to curb intrusions of the military into civilian politics, ${ }^{30}$ favored publication of the CIA budget, ${ }^{31}$ believed the Court should look into the question of whether more than 100 members of Congress were violating the incompatibility clause of the Constitution by holding reserve commissions in the armed forces, ${ }^{32}$ and urged the Court to pass on the constitutionality of the Vietnam War. ${ }^{33}$

25. Branzburg v. Hayes, 408 U.S. $665,724-25$ (1972).

26. United States v. Columbia Steel Co., 334 U.S. 495, 535 (1948).

27. Id. at 536.

28. The Right of the PEOPLE 11 (1958).

29. Youngstown Sheet \& Tube Co. v. Sawyer, 343 U.S. 579, 633 (1952).

30. Laird v. Tatum, 408 U.S. 1, 24-28 (1972).

31. United States v. Richardson, 418 U.S. 166, 197-202 (1974).

32. Schlesinger v. Reservists Comm. to Stop the War, 418 U.S. 208, 233-34 (1974).

33. Holtzman v. Schlesinger, 414 U.S. 1304, 1316, 1321 (1973). 
Similarly, Justice Douglas's conception of the positive role of the judiciary led him to reject the notion that judges could be "neutral," or could apply "neutral principles." In his view there was no such thing as "neutrality" in the work the courts had to do; to be "neutral" merely meant to preserve the status quo and ignore the problems that needed solution. Hence, he had no use for "judges so wedded to the status quo that critical analysis made them nervous." 34 He told Eric Severeid that he would rather create a precedent himself than find one. And since lawyers also played a central role in the process, he thought that they, too, should be bold and venturesome in maintaining and developing the constitutional structure of American society.

Finally, it was Justice Douglas's deep conviction that the social order in America could not stand still but must adapt to the changing times and the new problems. Justice Douglas not only accepted social change, but insisted on it. For him, America was an idea larger and better than the prevailing system. He was ever ready to oppose those interests and alter those institutions that fell short of American ideals. "If society is to be responsive to human needs," he wrote, "a vast restructuring of our laws is essential." 35

Justice Douglas's concern with transforming America carried to the point where, like Jefferson and Lincoln, he did not shy away from contemplating revolution. "Rebellion against government is a serious matter," he warned, but "revolution can be a righteous cause ... [and] the throwing off of chains by an oppressed people is a noble project." 36 In one dissenting opinion he wrote: "[S]ubmissiveness is not our heritage. The First Amendment was designed to allow rebellion to remain as our heritage." ${ }^{37}$ And about revolution, as about everything else, he was upbeat: "That revolution-now that the people hold the residual powers of government-need not be a repetition of 1776 . It could be a revolution in the nature of an explosive political regeneration." 38

Feeling as he did about social change, Justice Douglas was never greatly impressed by mere institutional competence. "The issues that challenge this generation call for bold and daring action," 39 he declared. "They demand men who live dangerously-men who place adventure ahead of security, men who would trade the comfort of today for the chance of scaling a new peak of progress tomorrow." 40 In this

34. Brandenburg v. Ohio, 395 U.S. 444,454 (1969).

35. Points of Rebellion 92 (1970).

36. An Almanac of Liberty, supra note 19, at 3.

37. Laird v. Tatum, 408 U.S. 1, 28 (1972).

38. Points of Rebellion, supra note 35 , at 97.

39. OF MEN AND Mountains, supra note 4, at 328.

40. $I d$. 
respect, he thought of radically minded lawyers, not as part of the Left, but as the very center of the American system.

Beneath Justice Douglas's call for social regeneration lay, as always, his profound feeling for the greatness of America and his passionate concern for its future. This was never better conveyed than at the close of his preface to his autobiography, Go East, Young Man:

The overall aim of this volume and the volume to follow is the hope that our people will come truly to love this nation. I hope it may help them see in the perspective of the whole world the great and glorious tradition of liberty and freedom enshrined in our Constitution and Bill of Rights. I hope they will come to love the continent, the most beautiful one in the whole world. I hope that before it is too late they will develop a reverence for our rich soils, pure waters, rolling grass country, high mountains, and mysterious estuaries. I hope that they will put their arms around this part of the wondrous planet, love it, care for it, and treat it as they would a precious and delicate child. ${ }^{41}$

Such was the Justice before whom lawyers with causes came to plead their cases. He lent an understanding ear, and his life and work should inspire many to mold themselves in his image.

41. Go EAST, Young MaN Xv (1974). 